University of Nebraska - Lincoln

DigitalCommons@University of Nebraska - Lincoln

Space, Cyber, and Telecommunications Law

Program Faculty Publications

2017

\title{
Transfer of Ownership in Orbit: From Fiction to Problem
}

Frans von der Dunk

Follow this and additional works at: https://digitalcommons.unl.edu/spacelaw

Part of the Air and Space Law Commons, Comparative and Foreign Law Commons, International Law Commons, Military, War, and Peace Commons, National Security Law Commons, and the Science and Technology Law Commons

This Article is brought to you for free and open access by the Law, College of at DigitalCommons@University of Nebraska - Lincoln. It has been accepted for inclusion in Space, Cyber, and Telecommunications Law Program Faculty Publications by an authorized administrator of DigitalCommons@University of Nebraska - Lincoln. 


\section{Transfer of Ownership in Orbit: from Fiction to Problem}

Frans von der Dunk*

\section{Abstract}

For many years, the concept of transfer of ownership of a satellite in orbit was not something on the radar screen of anyone seriously involved in space law, if indeed it was not considered a concept of an essentially fictional nature. Space law after all developed, as far as the key UN treaties were concerned, in a period when only States - and only very few States at that - were interested in and possessed the capability of conducting space activities, and they did so for largely military/strategic or scientific purposes. The idea of transferring ownership over satellites or other spacecraft involved in such endeavours simply did not make sense.

Leapfrogging the years, however, such transfer of ownership is no longer fiction, but rather an increasingly frequent fact of life on orbit. This in turn raises the question of what legal or other issues such events, not having been taken into consideration at all in the formative period of the major space treaties, would raise. This is essentially what the current contribution undertakes to investigate in a more or less comprehensive, albeit summary fashion.

\section{From Fiction to Fact}

With the gradual commercialization, then privatization of the satellite communications sector, roughly from the 1980s onwards, the idea of satellites as a commercial commodity, hence of ownership of such a satellite as being of commercial value and thereby possibly subject to commercial transactions, started to take hold.

Not accidentally therefore, the first event where this clearly came to the fore happened in the same timeframe. A Palapa-B2 satellite, launched on 3

* University of Nebraska - Lincoln. 
February 1984 from the United States by the Space Shuttle, was inserted into the wrong orbit, but because of its value to the insurers - the famous Lloyds - it was valuable enough to be retrieved and brought back to Earth by another Space Shuttle mission in November of the same year, to be relaunched on 13 April 1990 on a Delta rocket for an in-orbit handover to Permutal, the Indonesian government company henceforth running it. ${ }^{1}$

Since then, actual transfers of ownership of satellites while already in orbit started to occur with some frequency - often involving multiple countries. In 1992, BSkyB sold its Marcopolo-2 satellite, launched in 1990, to Norwegian Telecom, who renamed the satellite Thor. ${ }^{2}$ In 1993 Telesat Canada sold its Anik C1 and C2 satellites, both launched many years before, to Paracom, an Argentinian company which renamed them Nahuel I1 and I2 respectively. ${ }^{3}$ In 1996, BSkyB also sold its Marcopolo-1 satellite, in orbit since 1989, to the Swedish Nordic Satellite AB, which renamed it Sirius-1 - and in 2000 moved it from its position in geostationary orbit at $5.2^{\circ} \mathrm{E}$ to a position at $13^{\circ} \mathrm{W}$, where it better served its new owner's business purposes. ${ }^{4}$ More recently, the Korean entity KT Corporation entered the game, selling in 2009 and 2010 respectively its Koreasat-2 and Koreasat-1B, both launched into orbit by different launch service providers several years earlier, to the Bermuda-based company ABS with major Hong Kong shareholding which renamed them ABS-1A respectively ABS-7. ${ }^{5}$ KT Corporation nevertheless remained involved by providing TT\&C support for the satellites, of which the first was moved from the geostationary slot at $113^{\circ} \mathrm{E}$ to that at $74.8^{\circ} \mathrm{E}$. Most recently, in December 2014, Airbus Defence \& Space of France sold a Spot-7 remote sensing satellite, launched on 30 June 2014, to Azercosmos, the space agency of Azerbaijan, which immediately renamed it Azersky. ${ }^{6}$

1 See $e . g$. https://en.wikipedia.org/wiki/Palapa; http://www.sattel.com/life_of_palapa b2.htm; http://www.americaspace.com/?p=27134.

2 See e.g. https://en.wikipedia.org/wiki/Thor_(satellite); http://space.skyrocket.de/doc sdat/marco-polo.htm.

3 See e.g. https://en.wikipedia.org/wiki/Anik_(satellite); http://space.skyrocket.de/doc sdat/anik-a.htm.

4 See $e . g$. https://www.satellites.co.uk/forums/threads/bsb-marco-polo-1-2-31w.7380 6/; http://space.skyrocket.de/doc_sdat/marco-polo.htm.

5 See $e . g$. http://space.skyrocket.de/doc_sdat/koreasat-1.htm; http://space.skyrocket.d e/doc_sdat/koreasat-3.htm.

6 See e.g. https://en.wikipedia.org/wiki/SPOT_(satellite); http://space.skyrocket.de/do c_sdat/spot-6.htm. 
Though not strictly speaking amounting to transfer of ownership over a satellite while it is in orbit, several other events come close enough in terms of practical and legal consequences to be mentioned here as well. AsiaSat-1 and AsiaSat-2, owned by AsiaSat of Hong Kong, had been launched when Hong Kong was still part of the United Kingdom - but then, in 1997, Hong Kong reverted to China. ${ }^{7}$ In other words, this was not so much a case of transfer of ownership of a satellite in orbit, but a case of transfer of nationality of the owner of a satellite in orbit from one country to another.

Likewise, Telesat Canada, founded in 1989 as a Canadian company headquartered in Ottawa, with (presently) ownership over thirteen satellites and operational responsibility over thirteen more on behalf of other owners, in 2007 was bought for $64 \%$ by Loral, a US company. ${ }^{8}$ In other words, not a case of transfer of ownership of a satellite in orbit, but a case of transfer of ownership of an owner of satellites in orbit. Similar instances concerned LMI, having launched a LMI-1 satellite in 1996 before being acquired itself in 2006 by ABS, ${ }^{9}$ and Mabuhay Satellite Corporation, having an Agila-2 satellite operational since 1997 before then being acquired itself in 2009 by ABS, which renamed the satellite ABS-5. ${ }^{10}$

So indeed, the question has now become valid: does this raise legal problems or issues worthy of discussion, or does existing applicable space law now raise problems in practice for operators and/or governments concerned?

\section{Transfer of Ownership in Orbit in Existing Space Law}

The concept of 'transfer of ownership' is completely absent from the major space treaties referred to earlier. The Outer Space Treaty ${ }^{11}$ only refers to 'ownership' once, but interestingly in a manner neither seemingly to al-

7 See e.g. https://en.wikipedia.org/wiki/AsiaSat; http://space.skyrocket.de/doc_sdat/ asiasat-1.htm; https://en.wikipedia.org/wiki/AsiaSat_2.

8 See e.g. https://en.wikipedia.org/wiki/Telesat.

9 See $e . g$. http://space.skyrocket.de/doc_sdat/lmi-1.htm.

10 See e.g. https://en.wikipedia.org/wiki/Mabuhay_Satellite_Corporation; http://spac e.skyrocket.de/doc_sdat/agila-2.htm.

11 Treaty on Principles Governing the Activities of States in the Exploration and Use of Outer Space, including the Moon and Other Celestial Bodies (hereafter Outer Space Treaty), London/Moscow/Washington, done 27 January 1967, entered into 
low for anything like transfer thereof, nor resulting in any change with regard to the law existing prior to the Treaty's establishment: "Ownership of objects launched into outer space, including objects landed or constructed on a celestial body, and of their component parts, is not affected by their presence in outer space or on a celestial body or by their return to the Earth."12

While the concept of 'ownership' is completely absent from the Rescue Agreement ${ }^{13}$, the Liability Convention ${ }^{14}$ and the Registration Conventi${ }^{o n}{ }^{15}$, the Moon Agreement merely echoes the above stipulation of the Outer Space Treaty: "The ownership of space vehicles, equipment, facilities, stations and installations shall not be affected by their presence on the Moon". ${ }^{16}$

Also the ITU Constitution ${ }^{17}$, ITU Convention ${ }^{18}$ and ITU Radio Regulations ${ }^{19}$, the main triad of ITU treaty documents providing another set of

force 10 October 1967; 610 UNTS 205; TIAS 6347; 18 UST 2410; UKTS 1968 No. 10; Cmnd. 3198; ATS 1967 No. 24; 6 ILM 386 (1967).

12 Art. VIII, Outer Space Treaty (supra, n. 11).

13 Agreement on the Rescue of Astronauts, the Return of Astronauts and the Return of Objects Launched into Outer Space (hereafter Rescue Agreement), London/ Moscow/Washington, done 22 April 1968, entered into force 3 December 1968; 672 UNTS 119; TIAS 6599; 19 UST 7570; UKTS 1969 No. 56; Cmnd. 3786; ATS 1986 No. 8; 7 ILM 151 (1968).

14 Convention on International Liability for Damage Caused by Space Objects (hereafter Liability Convention), London/Moscow/Washington, done 29 March 1972, entered into force 1 September 1972; 961 UNTS 187; TIAS 7762; 24 UST 2389; UKTS 1974 No. 16; Cmnd. 5068; ATS 1975 No. 5; 10 ILM 965 (1971).

15 Convention on Registration of Objects Launched into Outer Space (hereafter Registration Convention), New York, done 14 January 1975, entered into force 15 September 1976; 1023 UNTS 15; TIAS 8480; 28 UST 695; UKTS 1978 No. 70; Cmnd. 6256; ATS 1986 No. 5; 14 ILM 43 (1975).

16 Art. 12(1), Agreement Governing the Activities of States on the Moon and Other Celestial Bodies (hereafter Moon Agreement), New York, done 18 December 1979, entered into force 11 July 1984; 1363 UNTS 3; ATS 1986 No. 14; 18 ILM 1434 (1979).

17 Constitution of the International Telecommunication Union (hereafter ITU Constitution), Geneva, done 22 December 1992, entered into force 1 July 1994; 1825 UNTS 1; UKTS 1996 No. 24; Cm. 2539; ATS 1994 No. 28; Final Acts of the Additional Plenipotentiary Conference, Geneva, 1992 (1993), at 1.

18 Convention of the International Telecommunication Union (hereafter ITU Convention), Geneva, done 22 December 1992, entered into force 1 July 1994; 1825 UNTS 1; UKTS 1996 No. 24; Cm. 2539; ATS 1994 No. 28; Final Acts of the Additional Plenipotentiary Conference, Geneva, 1992 (1993), at 71. 
legal instruments indispensable for space activities in view of the need for interference-free usage of certain radio frequencies, do not contain a single reference to the concept of 'ownership', let alone of 'transfer of ownership'.

This is perhaps not surprising, as the legal concept of 'ownership' is essentially a private law notion, and all the above key treaties are fundamentally of a public international law-character. For the same reasons, the only international treaty relevant to space and fundamentally addressing ownership issues is not only a very recent one, but one addressing private international law issues at that: the UNIDROIT Space Assets Protocol of $2012 .{ }^{20} \mathrm{In}$ its efforts to establish an international register of securities in space assets and an internationally harmonized regime for dealing with default remedies and procedures in order to ease the financing of certain commercial space operations, the ownership (or other closely-related concepts such as lease) of (amongst others) satellites is at least addressed three times..$^{21}$ However, the Space Assets Protocol is not in force, and neither does it look like it will soon enter into force - so effectively the concept of 'ownership' does not really exist in, at least, the main space treaties relevant for satellite communications.

\section{3. 'So what's the Problem?'}

Thus, the next question may be raised: what is the problem with any changes of ownership (whether of satellites in orbit or otherwise) being basically ignored by space law and taking place, legally speaking, completely outside of what those treaties undertook to address and regulate? The key to the answer seems to lie in the practical fact of life that 'ownership' usually also means 'control', and certainly with items of such a special character as high-value satellites, operated by expensive and dedicated ground stations, this would apply more or less across the board. Such con-

19 Radio Regulations Articles, Edition of 2012 (hereafter Radio Regulations), www.it u.int/pub/R-REG-RR-2012.

20 Protocol to the Convention on International Interests in Mobile Equipment on Matters Specific to Space Assets (hereafter Space Assets Protocol), Berlin, done 9 March 2012, not yet entered into force; UNIDROIT Doc., DCME-SP-Doc. 43.

21 Cf. Arts. I(2.h), III, XX(4), Space Assets Protocol (supra n. 20). 
trol furthermore does raise two distinct and very fundamental issues under current space law.

On the one hand, such 'control' over a satellite also effectively means control over the activities it undertakes. This directly raises the potential for international responsibility of a State to arise, as every State is responsible "for national activities in outer space, including the Moon and other celestial bodies, whether such activities are carried on by governmental agencies or by non-governmental entities, and for assuring that national activities are carried out in conformity with the provisions set forth in the present Treaty. The activities of non-governmental entities in outer space, including the Moon and other celestial bodies, shall require authorization and continuing supervision by the appropriate State Party to the Treaty". ${ }^{22}$

This, in short, has major legal consequences also for commercial satellite communications, the sector where the concept of 'transfer of ownership' is most present and relevant. Most prominently, States are thereby held responsible for private space activities as if they were their own. States carrying such responsibility would be required to exercise in turn some form of legal control, in line with the obligations of 'authorization and continuing supervision', over whatever private 'activities in outer space' they consider, in the absence of uniformly agreed interpretations of this concept at the international level ${ }^{23}$, 'national', normally by way of a licensing system ${ }^{24}$. If then the satellite, subject to such licensing or (in any event) falling under the relevant State's responsibility, changes hands, issues of continuing applicability of the license and, in case of an internatio-

22 Art. VI, Outer Space Treaty (supra n. 11).

23 Generally, whereas individual States have their own specific interpretation or mode of implementation, amongst experts three generic interpretations can be discerned: (1) 'national' activities are those 'of nationals' (whether natural or legal persons), (2) 'national' activities are those for which the State qualifies as the 'launching State' (as that concept triggers liability for damage - see further infra), and (3) 'national' activities are those over which a State can exercise jurisdiction either on a personal or on a territorial basis. See e.g. F.G. von der Dunk, International Space Law, in Handbook of Space Law (Ed. F.G. von der Dunk) (2015), 53-4.

24 So far, more than a dozen states have actually established national space legislation prominently including such a licensing system for private operators; see further e.g. I. Marboe, National Space Law, in Handbook of Space Law (Ed. F.G. von der Dunk)(2015), 130-204. 
nal change of hands even the national licensing regime as such, become an issue. Thus the purely private-law character of transfer of ownership, by virtue of the equation of private to governmental space activities for the purpose of international responsibility, becomes a matter of public law and policy under the Outer Space Treaty.

Following up on that, although the aforementioned clause strictly speaking refers to compliance with the Outer Space Treaty itself only, due to the latter's fundamental character in defining the legal framework for all space activities and its blanket application of general international law thereto by virtue of Article III ${ }^{25}$, such State responsibility effectively refers to compliance with international law as applicable in outer space comprehensively. In that sense, the control of the activity as normally following from ownership of the satellite used for that activity pertains to ensuring its conformity with other rules of the space treaties (such as the obligation to have a satellite properly registered, both nationally and internationally ${ }^{26}$ ) but also for example with the ITU regime on allocation, allotment and assignment of orbital frequencies and slots. ${ }^{27}$

On the other hand, of course, 'control' over a space object legally speaking carries with it the potential for international liability of a State to arise as a consequence of actions of such a 'controller': under the Liability Convention, States are internationally liable for space objects in respect of which they qualify as the or a launching State - regardless of whether that space object is owned, controlled, or operated by a private operator. ${ }^{28}$

This again means that States are, if not formally required, at least strongly incentivised to exercise legal control over such space objects, as they would - in first instance at least - have to foot the bill in case it causes damage in an international setting. Indeed, most States having established some form of licensing system, as indicated before, have also taken care to include in that context requirements related to liability, reimbursement of

25 Art. III, Outer Space Treaty (supra n. 11), provides: "States Parties to the Treaty shall carry on activities in the exploration and use of outer space, including the Moon and other celestial bodies, in accordance with international law, including the Charter of the United Nations, in the interest of maintaining international peace and security and promoting international cooperation and understanding.".

26 See Arts. II-IV, Registration Convention (supra n. 15).

27 See e.g. Arts. 1(2)(a), 44, ITU Constitution (supra n. 17); Arts. 4, 5, Radio Regulations (supra n. 19).

28 See Arts. I(c), II-V, Liability Convention (supra n. 14). 
the government in case of international claims and appropriate third-party liability insurance. ${ }^{29}$

In view of the nature of State liability - 'once a launching State, always liable' - a transfer of ownership in orbit may, again, raise questions of applicability of the license handling such liabilities, or more fundamentally in case of an international transfer, of jurisdiction of the still-liable State over the operations of a foreign entity which may result in damage that the State would have to cover under the Liability Convention.

This is further aggravated by the system of registration, where based upon the same launching State criterion a State may in theory exercise quasi-territorial jurisdiction over the satellite, but in case of an international transfer of ownership may actually see such a possibility slip out of sight, whilst the 'new' State of nationality of the new owner may not have such opportunities to obtain jurisdiction by way of registration if it was not at least an original launching State of that space object itself. ${ }^{30}$

In summary, to the extent that private ownership of a satellite indeed translates into private control thereof and of the activities it is undertaking in outer space, potential interaction with the sphere of jurisdiction and control of a State arises - and if the ownership then changes, this system is completely disrupted.

\section{Back to Practice: Confusion Rules}

The result, also in practice, is a considerable amount of confusion regarding the extent of international responsibility and/or liability of the various States implicated in ownership of satellites and the transfer thereof, and the extent of such obligations as authorization, continuing supervision and registration of satellites. The exemplary set of transfers of ownership listed before shows ample proof of such confusion, resulting in potentially harmful gaps and overlaps of individual States' actions.

The Palapa-B2 satellite retrieved in 1984 (which had not yet been registered with the United Nations at the time, in the half year until its retrieval), after its re-launch in April 1990 from US territory on a Delta launch vehicle operated by the US company McDonnell Douglas, was registered

29 See further e.g. Marboe (supra, n. 24), $138 \&$ ff.

30 Cf. e.g. Art. VIII, Outer Space Treaty (supra n. 11), in combination with Art. II, Registration Convention (supra n. 15). 
by the United States with the United Nations on 17 January $1992 .{ }^{31}$ This was logical as the United States was clearly the (or at least a) launching State of the satellite, and thus automatically entitled to register. However, it was then handed over in orbit to Permutal, an Indonesian government company, whereas the United States in contrast remained liable under the Liability Convention for any international liability that the satellite could cause without a possibility of direct recourse to Permutal, as the latter was not licensed by the former. ${ }^{32}$ Since the launch was actually at least indirectly procured by Permutal ("the Palapa B2R spacecraft (...) is the responsibility of SATTEL, a United States company, during initial on-orbit checkout, after which time the satellite will be turned over to PERMU$\mathrm{TAL}$, an Indonesian government corporation" ${ }^{\prime 3}$ ) Indonesia might arguably have qualified as the other launching state and, by that token, would have been able to exercise jurisdiction as a State of registration - but did not.

Next was the case of the Marcopolo-2. Its original owner BSkyB is a UK company which had procured the launch on 17 August 1990 from US territory on a Delta launcher from the US company McDonnell Douglas. As the UK Outer Space Act also requires a license from a UK company for procuring a satellite's launch, ${ }^{34}$ the United Kingdom clearly perceived itself to be a launching State, and hence registered the satellite with the United Nations on 8 July $1991 .{ }^{35}$ So far, so good. However, no doubt partly due to the lack of a Norwegian register in the first place ${ }^{36}$, when the satellite - long after its 1992 transfer-in-orbit to Norwegian Telecom - was moved to a graveyard orbit, it was again the United Kingdom, as one of

31 See ST/SG/SER.E/250.

32 While it may be presumed that the launch contract would take care of such liabilities, as insisted upon by the United States when licensing the re-launch in the first place, the contracts containing such clauses usually remain commercially confidential (making it difficult to judge on their efficacy and appropriateness) and in any event complicate the ultimate handling of international liability claims which the United States would have to honour in principle.

$33 \mathrm{ST} / \mathrm{SG} / \mathrm{SER} . \mathrm{E} / 250$, at 8.

34 See Secs. 1(a), 2(1), Outer Space Act (hereafter UK Outer Space Act), 18 July 1986, 1986 Chapter 38; National Space Legislation of the World, Vol. I (2001), at 293; Space Law - Basic Legal Documents, E.I; 36 Zeitschrift für Luft- und Weltraumrecht (1987), 12.

35 See ST/SG/SER/E/241.

36 Norway notified the United Nations of the establishment of a national register only as of 21 January 2014; see ST/SG/SER.E/INF/29. 
the original launching States and the State of registry of duty, who (on 15 June 2007) informed the United Nations of such a manoeuvre. ${ }^{37}$

One year upon the heels of Marcopolo-2's sale-in-orbit followed that of the two Anik satellites. Both had been launched on the US Space Shuttle from the United States, on 12 April 1985 and 18 June 1983, respectively. Though Telesat Canada, the procurer of the launch, was not a Canadian government company but a private Canadian one (making it at least debatable whether Canada on that count should qualify as a 'launching State'), and though Canada did not have a full-fledged licensing system for private space operations in place, both satellites were registered with the United Nations by Canada on 6 February 1987.38 Long after their 1993 sale to Paracom, an Argentine company, both satellites were retired (on 5 May 2003 and 7 January 1998, respectively) ${ }^{39}$ - but no notification thereof has ever made it to the UN register, in spite of the fact that Argentina had notified the United Nations of the establishment of its national register on 30 December $1996 .{ }^{40}$

Back to the other BSKyB satellite sold on-orbit: the Marcopolo-1. That satellite, like its brother, had been launched on a Delta by McDonnell Douglas from US territory (on 27 August 1989) and registered with the United Nations by the UK authorities (on 12 April 1990). ${ }^{41}$ Again, the United Kingdom also under its own interpretation was to be considered a 'launching State'. BskyB, however, sold this Marcopolo satellite to a new operator from a country which already had a national register: NSAB from Sweden. Sweden consequently notified the United Nations of inclusion of the now renamed Sirius-1 in its national register on 1 February $1999 .{ }^{42}$ The satellite was then moved (in 2000) from one geostationary position to another (from $5.2^{0} \mathrm{E}$ to $13^{0} \mathrm{~W}$ ); which information was also for-

37 See ST/SG/SER/E/518.

38 See ST/SG/SER/E/156.

39 See https://en.wikipedia.org/wiki/Anik_(satellite).

40 See ST/SG/SER.E/INF.13.

41 See ST/SG/SER.E/219.

42 See ST/SG/SER.E/352. Note that Sweden never formally notified the United Nations of establishment of its national register, although as of 1986 (when its national register was actually established, as per Sec. 4, Decree on Space Activities, 1982: 1069; National Space Legislation of the World, Vol. I (2001), at 399; Space Law - Basic Legal Documents, E.II.2; 36 Zeitschrift für Luft- und Weltraumrecht (1987), 11) it had started to send notifications to the United Nations; $c f$. ST/SG/ SER.E/145. 
warded to the United Nations by Sweden. ${ }^{43}$ However, when the satellite was ultimately removed to a graveyard orbit, it was again the United Kingdom which so notified the United Nations on 15 June 2007.44

Our next example came from the Asia-Pacific region, where Koreasat-2 had been sold by KT Corporation, a South Korean company, to ABS, which is based in Bermuda but seems to have fundamental ties with Hong Kong as well. The satellite had originally been launched on 14 January 1996 on a Delta launch vehicle from the United States, and had been registered with the United Nations on 11 March 1996 by South Korea ${ }^{45}$ even as, in view of KT Corporation's private legal status, the status of South Korea as 'launching State' was much more in doubt than that of the United States. Also after its handover to ABS in 2009, however, KT continued to provide telemetry, tracking and control services for the satellite and on 13 December 2013, South Korea provided additional information on the satellite's move from $113^{\circ} \mathrm{E}$ to $74.8^{\circ} \mathrm{E}$ and the transfer of its ownership to ABS - four years after the fact. ${ }^{46}$

A similar situation arose with Koreasat-1B, sold one year after its sister satellite by the same KT Corporation to the same ABS - except this time it had been launched (on 5 September 1999) on an Ariane launcher from French Guiana, making France the potential other State of registry instead of the United States - and the more undisputed one compared to South Korea. However, once again, South Korea registered the satellite with the United Nations (on 18 September 1999), ${ }^{47}$ whilst KT Corporation continued to provide telemetry, tracking and control services for the satellite.

The last example of sale-in-orbit concerned the Spot-7, launched on behalf of the French company Airbus Defence \& Space on 30 June 2014, on top of a PSLV launch vehicle by the Indian Space Research Organisation (ISRO) from India. Soon after, it was handed over to Azercosmos, the national space agency of Azerbaijan - but in any event, whichever State might have considered itself the appropriate 'launching State', it has not been registered with the United Nations (yet).

The special scenario which developed in the cases of AsiaSat-1 and AsiaSat-2, of transfer of nationality of the owner of a satellite concomitant

\footnotetext{
43 See ST/SG/SER.E/377.

44 See ST/SG/SER.E/518.

45 See ST/SG/SER.E/304.

46 See ST/SG/SER.E/304/Add.1.

47 See ST/SG/SER.E/362.
} 
to a transfer of sovereignty of the registration authority, was handled much better, in spite of some strictly legal complications. Owned by AsiaSat, a Hong Kong company, they were launched on 7 April 1990 and 28 November 1995, respectively, that is at a time when Hong Kong was still part of the United Kingdom. Consequently, the United Kingdom had registered both launches with the United Nations on 15 May 1990 respectively 23 January 1996. ${ }^{48}$ When Hong Kong in 1997 reverted from the United Kingdom to China, it was almost a stroke of luck that both satellites had been launched on Long March launch vehicles operated by the China Great Wall Industrial Corporation, the Chinese governmental launch provider, from China. Even though under the Registration Convention's provisions re-registration was not formally allowed, China's status as original colaunching state made it easier for China to notify the United Nations of the relevant changes. China had as a matter of fact started notifying the United Nations of launches conducted from China in $1990^{49}$, but as it had established a national register in 2001 and only notified that establishment to the United Nations in $2005^{50}$, it only informed the United Nations of the transfer of ownership to China and of the removal of Asiasat-1 to a graveyard orbit on 8 June 2005.

The other special scenario briefly discussed above, of transfer of ownership of a company owning satellites, concerned amongst others the aforementioned Telesat Canada, founded in 1989 and headquartered as a company in Canada but as of 2007 becoming majority-owned by the US Company Loral. Nevertheless, Canada until 2008 continued to notify the United Nations of satellites launched on behalf of Telesat Canada, the last one being the Nimiq- $4 .{ }^{51}$ The next Telesat Canada satellite, Nimiq-5, was not formally registered at all, but since being launched in 2009 by Russia, was mentioned in a side-note in a Russian note verbale to the United Nations of 10 May 2010.52 The same applies to the Telstar-14R and Nimiq-6, the only further satellites launched by Telesat since Loral's take-over of the company. ${ }^{53}$

48 See ST/SG/SER.E/222 resp. ST/SG/SER.E/300.

49 See ST/SG/SER.E/229.

50 See ST/SG/SER.E/INF.17.

51 See ST/SG/SER.E/597. More broadly: http://www.unoosa.org/oosa/osoindex/searc h-ng.jspx?lf id=, type in 'Telesat Canada' in 'Search Object' box.

52 See ST/SG/SER.E/593.

53 See ST/SG/SER.E/624 resp. ST/SG/SER.E/661. 
Another example of the same scenario pertained to LMI-1, launched in 1999 on a Proton vehicle from Baikonur in Kazakhstan for the LMI international consortium formed by a US private company and an intergovernmental organization dominated by Russia. Russia informed the United Nations of this launch by way of another side-note in a Russian note verbale of 10 December 1999, specifically adding that this concerned a "United States telecommunications satellite". ${ }^{54}$ Then, of course, LMI was acquired by ABS in 2006 - but this information did not make it to the UN register.

Finally, there was Agila-2, launched in 1997 from China and registered with the United Nations in 2003 by the Philippines ${ }^{55}$ since the owner of the satellite, Mabuhay Satellite Corporation, was a Philippine entity even as it was a private corporation, its procurement of the launch was perceived by the Philippines to qualify them as launching State, a prerequisite for serving as State of registry. The Corporation was itself acquired in 2009 by ABS, the satellite renamed ABS- 5 - but this information did not make it to the $\mathrm{UN}$ register either.

\section{Concluding Remarks}

The above survey, not even complete in itself, already shows the complications in the legal realm that have resulted from the introduction of normal commercial private-law practices such as transfer of ownership (or indeed of leasing of spacecraft and/or transponders in orbit) into the space arena by way of transfer of ownership in orbit, where (public, international) space law has largely remained unchanged since the early days.

The system of registration of space objects was established in the 1960s and 1970s with the aim to create as much transparency as possible on the whereabouts of operational (and non-operational) space objects and on which State would be responsible and liable for activities conducted therewith and damage caused thereby. It may have been suffering from legal and practical flaws from the start, ${ }^{56}$ but it is now receiving a different kind of blow from those transfers of ownership of various kinds, which increasingly raises problems in practice of actual governmental oversight.

54 ST/SG/SER.E/367.

55 See A/AC.105/INF.409.

56 Cf. e.g. Y. Lee, Registration of Space Objects: ESA Member States' Practice, 22 Space Policy (2006), 42-51. 
Satellites remain unregistered or key information on their operation or ownership goes unnoticed (at least at the UN level), very likely at least in part because of confusion or tactical ignorance, made possible thereby, of who should take the lead in this respect. Which State, indeed, is responsible for a satellite's operations: the one (of nationality of the entity) owning it or the one (of nationality of the entity) tracking and controlling it operationally? Which State(s), originally involved as launching State(s), consider themselves still liable after the ownership has moved to (the entity from) a third country? Who should register in these complex scenarios, where formally re-registration is anyway not envisaged by the Registration Convention, and who should exercise jurisdiction? And over what part of a spacecraft, noting the further problems thrown into the mix in this context by the Space Assets Protocol?

The most positive thing that can be said as of today, is that no serious consequences have resulted - at least as far as can be seen from the outside. Yet, it could only be presumed that the practices discussed above will continue to become more extended, varied and complicated as both the number of State players in outer space and the number and range of nonstate players continues to increase. With the huge investments at stake in a commercial context, not to mention the public interests in maintaining a sustainable space environment for all States of the world and free and beneficial exploration and use of outer space in deference to the Outer Space Treaty, major accidents are only waiting to happen: it would be a mistake to not start thinking seriously now about how to address these issues.

\section{Bibliography}

Lee, Y., Registration of Space Objects: ESA Member States' Practice, 22 Space Policy (2006), 42-51.

Marboe, I., National Space Law, in Handbook of Space Law (Ed. F.G. von der Dunk) (2015), 127-204.

Schmidt-Tedd, B., et al., The 1975 Convention on Registration of Objects Launched into Outer Space, in Cologne Commentary on Space Law (Eds. S. Hobe, B. Schmidt-Tedd \& K.U. Schrogl) Vol. II (2013), 227-324.

Smith, L.J., A. Kerrest de Rozavel \& F. Tronchetti, The 1972 Convention on International Liability for Damage Caused by Space Objects, in Cologne Commentary on Space Law (Eds. S. Hobe, B. Schmidt-Tedd \& K.U. Schrogl) Vol. II (2013), 83-226.

Sundahl, M.J., Financing space ventures, in Handbook of Space Law (Ed. F.G. von der Dunk)(2015), 874-909. 


\section{Transfer of Ownership in Orbit: from Fiction to Problem}

Von der Dunk, F.G., International Space Law, in Handbook of Space Law (Ed. F.G. von der Dunk)(2015), 29-126. 